Lukman Effendy: Determinan Return Saham...

\title{
DETERMINAN RETURN SAHAM SUATU PENDEKATAN FUNDAMENTAL
}

\author{
Lukman Effendy \\ Fakultas Ekonomi Dan Bisnis Universitas Mataram \\ lukman.effendy@unram.ac.id
}

\begin{abstract}
ABSTRAK
Penelitian ini bertujuan untuk menguji secara empiris faktor fundamental yaitu inflasi, suku bunga, exchange rate, return on asset (ROA) dan Debt to Equity Ratio (DER), terhadap return saham. Populasi yang digunakan adalah perusahaan perbankan yang terdaftar di Bursa Efek Indonesia tahun 2012-2016. Penentuan sampel dalam penelitian ini menggunakan metode purposive sampling, sehingga diperoleh 88 sampel perusahaan perbankan. Hasil penelitian menunjukkan variabel independen inflasi, suku bunga, exchange rate, return on asset (ROA) dan Debt to Equity Ratio (DER) baik secara parsial maupun secara simultan tidak berpengaruh terhadap return saham perusahaan perbankan yang terdaftar di BEI tahun 2012-2016.
\end{abstract}

Kata Kunci: Return saham, ROA, DER, Inflasi, Suku Bunga Indonesia.

\section{PENDAHULUAN}

Setiap perusahaan berkeinginan untuk memperluas dan mengembangkan usahanya dengan tujuan memperoleh laba yang meningkat. Perkembangan suatu perusahaan dapat dilihat dari segi kualitas produk yang dihasilkan, teknologi yang digunakan, tenaga kerja yang berkualitas, maupun kinerja perusahaan secara keseluruhan. Di era globalisasi sekarang ini, semua itu sangatlah penting agar perusahaan dapat bersaing di pasar domestik maupun internasional. Untuk dapat melakukan hal tersebut, perusahaan memerlukan dana yang cukup besar. Dana tersebut akan digunakan untuk kegiatan operasional perusahaan, seperti membeli bahan baku, membayar gaji karyawan, dan biaya overhead pabrik. Oleh sebab itu, perusahaan yang mengalami kekurangan dana dapat menerbitkan sahamnya di pasar modal dengan tujuan untuk memperoleh investor yang ingin menanamkan modalnya pada perusahaan dengan cara membeli saham dari perusahaan tersebut (Asri dan Suwarta, 2014).

Perusahaan yang melakukan investasi akanmendapatkan keuntungan ataupengembalian (return). Return yang bisa didapatkan oleh investor atas 
investasinya dapat berupa capital gain maupun dividen. Capital Gain merupakan besaransaham yang bisa memberikan keuntungan bagi investor. Sedangkan return bisa didapatkan oleh investor atas selisih harga beli dengan harga jual instumen investasinya.

Beberapa pertimbangan akan dibuat oleh seorang investor, sebelum berinvestasi. Bagi sebagian investor, mereka akan mendasarkan keputusan pada data-data historis pergerakan harga saham. Mereka menjadikan faktorfaktor fundamental sebagai bagian kecil pertimbangan untuk mengambil keputusan. Bagi sebagaian investor yang lain, mereka akan mendasarkan keputusan pada faktor-faktor fundamental, baik yang sifatnya makro maupun mikro perusahaan.

Faktor fundamental yang sifatnya makro adalah faktor eksternal juga dapat mempengaruhi return saham. Inflasi adalah faktor eksternal yang dapat mempengaruhi return saham. Menurut Prihantini (2009), Inflasi akan menyebabkan kenaikan harga barang dan jasa yang menyebabkan daya beli masyarakat menurun. Dari sisi perusahaan, penurunan daya beli masyarakat akan mengakibatkan berkurangnya pangsa pasar, sehingga pendapatan dan laba yang diperoleh perusahaan juga menurun. Tentu, pendapatan dan laba yang menurun ditanggapi oleh pasar dengan koreksi harga saham, dan pada akhirnya berdampak pada penurunan return saham. Beberapa penelitian sebelumnya tentang hal ini adalah seperti Laksmiwati (2009) membuktikan bahwa inflasi tidak berpengaruh terhadap return saham. Sementara, penelitian Prihantini (2009), Rusliati dan Fathoni (2011), dan Sudarsono dan Sudiyatno (2016) menunjukkan bahwa inflasi berpengaruh negatif dan signifikan terhadap return saham.

Faktor makro yang fundamental berikutnya adalah suku bunga. Suku bunga yang tinggi, akan menyebabkan investor melakukan shifting dari investasi saham ke investasi berupa tabungan dan deposito. Suku bunga berpengaruh negatif terhadap tingkat return. Penelitian yang dilakukan oleh Sudarsono dan Sudiyatno (2016) membuktikan bahwa tingkat suku bunga berpengaruh positif signifikan terhadap return saham. Laksmiwati (2009) membuktikan bahwa BI rate tidak berpengaruh terhadap return saham. Penelitian yang dilakukan oleh Rusliati dan Fathoni (2011) dan Widyastuti dan Andamari (2012) membuktikan bahwa suku bunga berpengaruh negatif signifikan terhadap return saham.

Faktor makro fundamental lain yang berpengaruh adalah nilai tukar. Menurunnya exchange rate akan menyebabkan penurunan nilai saham perusahaan, yang mengakibatkan return saham negatif. Pengaruh negatif ini diteliti oleh Ouma dan Muriu (2014) dalam Sudarsono dan Sudiyatno (2014). 
Hasil yang berbeda dinyatakan oleh Hayat dan Ahmed (2014) dalam Sudarsono dan Sudiyatno (2014).

Selain Faktor Makro Fundamental, terdapat juga faktor mikro fundamental (internal perusahaan) yang dapat mempengaruhi return saham, di antaranya ialah rasio Debt to Equity Ratio (DER). Tingkat DER yang tinggi menunjukkan komposisi total hutang semakin besar apabila dibandingkan dengan total modal sendiri yang berarti sumber modal perusahaan sangat tergantung dari pihak eksternal, sehingga mengurangi minat investor dalam menanamkan dananya di perusahaan tersebut. Penurunan minat investor akan berdampak pada penurunan harga saham perusahaan, sehingga return saham juga akan menurun. Anisa (2015) membuktikan bahwa Debt to Equity Ratio (DER) berpengaruh positif terhadap return saham. Hasil penelitian ini didukung oleh penelitian Sudarsono dan Sudiyatno (2016). Sedangkan, penelitian yang dilakukan oleh Prihantini (2009), Patriawan (2011) dan Verawati (2014) dalam Adiputra (2017) menunjukkan sebaliknya.

Selain Faktor DER, faktor yang mempengaruhi Return saham adalah faktor return on asset (ROA). Return on Asset (ROA) seringkali digunakan untuk mengukur kinerja perusahaan. Semakin besar ROA berarti kemampulabaan perusahaan akan semakin baik, sehingga akan meningkatkan capital gain yang bisa dibayarkan oleh perusahaan kepada para pemegang saham. Puspitasari (2012) membuktikan bahwa Return on Asset berpengaruh negatif dan tidak signifikan terhadap return saham. Hasil penelitian ini didukung oleh penelitian Sudarsono dan Sudiyatno (2016). Sementara, penelitian Prihantini (2009), Ross (2014), dan Anisa (2015) menunjukkan bahwa Return on Asset (ROA) berpengaruh positif dan signifikan terhadap return saham.

Berdasarkan perbedaan hasil penelitian (research gap) di atas, maka peneliti tertarik untuk meneliti kembali mengenai return saham pada perusahaan perbankan yang terdaftar di Bursa Efek Indonesia tahun 20122016. Alasan peneliti melakukan penelitian pada perusahaan perbankan karena perusahaan perbankan yang terdaftar di Bursa Efek Indonesia jumlahnya semakin bertambah. Pada tahun 2012 jumlah perusahaan perbankan yang terdaftar di BEI berjumlah 31 perusahaan dan sampai tahun 2016 jumlah perusahaan perbankan yang terdaftar di BEI berjumlah 43 perusahaan (www.sahamok.com). Dengan semakin banyaknya perusahaan perbankan yang terdaftar di BEI membuat bertambahnya pilihan investasi bagi investor pada sektor perbankan. Oleh karena itu, informasi terkait return saham penting untuk investor. Karena return saham adalah suatu faktor yang dapat mempengaruhi investor dalam melakukan investasi pada suatu perusahaan. 


\section{LANDASAN TEORI}

\section{Teori Efisiensi Pasar (Market EfficiencyTheory)}

Teori efisiensi pasar adalah teori yang membahas tentang harga atau nilai sekuritas yang mencerminkan secara penuh semua informasi yang tersedia pada informasi tersebut Jogiyanto (2010). Jadi dalam konsep efisiensi pasar ini membahas tentang hubungan antara harga atau nilai sekuritas dengan informasi, bagaimana pasar bereaksi terhadap informasiinformasi tersebut serta sejauh mana informasi tersebut dapat mempengaruhi pergerakan harga yang baru.

\section{Bentuk-bentuk EfisiensiPasar}

Menurut Jogiyanto (2010), bentuk-bentuk efisiensi pasar yaitu:

1. Efisiensi pasar dari sudut informasi (informationally efficient market)

a. Efisiensi pasar bentuk lemah (weakform)

b. Efisiensi pasar bentuk setengah kuat (semistrongform)

c. Efisiensi pasar bentuk kuat (storngform)

Jadi efisiensi pasar secara informasi didasarkan pada ketersediaan informasi harga atau nilai dari sekuritas mencerminkan semua informasi dan informasi tersebut dapat diperoleh secara terbuka dan cepat tanpa ada hambatan yang khusus.

2. Efisiensi pasar dari sudut keputusan (decisionally efficientmarket)

a. Pasar dikatakan efisien secara keputusan dapat dilihat dari kemampuan pelaku pasar dalam mengambil keputusan berdasarkan semua informasi yangtersedia.

b. Pasar dikatakan efisien jika terdapat ketersediaan informasi dan efisien secara informasi belum tentu efisien secarakeputusan.

Harga-harga saham mencerminkan semua informasi yang didalamnya mengandung informasi mengenai risiko investasi yang akan ditanggung oleh investor atau kreditor. Penurunan dan peningkatan harga saham yang berimplikasi pada return saham, menunjukkan adanya informasi baru baik yang sifatnya buruk maupun baik, yang dimiliki oleh para investor atau para pemegang saham. 
Lukman Effendy: Determinan Return Saham...

\section{Inflasi}

Menurut Bank Indonesia inflasi adalah kecenderungan kenaikan harga barang dan jasa secara umum dan bersifat persisten. Inflasi adalah ukuran ekonomi yang memberikan gambaran tentang meningkatnya harga rata-rata barang dan jasa yang di produksi pada suatu sistem perekonomian (Prihantini, 2009). Ruslihati dan Fathoni (2011) mengungkapkan bahwa inflasi akan menyebabkan harga barang dan jasa mengalami kenaikan yang menyebabkan daya beli masyarakat menurun, sehingga laba yang diperoleh perusahaan juga menurun dan pada akhirnya berdampak pada penurunan return saham.

\section{Suku Bunga}

Menurut Sudarsono dan Sudiyatno (2016) suku bunga adalah harga dari penggunaan uang untuk jangka waktu tertentu atau harga dari penggunaan uang yang dipergunakan pada saat ini dan akan dikembalikan pada saat mendatang. BI rate adalah suku bunga dengan tenor satu bulan yang diumumkan oleh Bank Indonesia secara periodik untuk jangka waktu tertentu yang berfungsi sebagai sinyal (stance) kebijakan moneter (Prakoso dan Boentoro, 2012). Tingginya suku bunga yang ditawarkan oleh sektor keuangan menyebabkan investor menarik investasinya pada saham dan memindahkannya pada investasi berupa tabungan dan deposito (Widyastuti dan Andamari, 2012). Suku bunga meningkat akan menyebabkan harga saham menurun dan juga akan berdampak pada turunya return saham. Iswardono (1999) dalam Sudarsono dan Sudiyatno (2016) menyatakan kenaikan suku bunga akan berakibat terhadap menurunnya return saham, begitu juga sebaliknya.

\section{Exchange Rate}

Definisi exchange rate (nilai tukar) antara lain dikemukan oleh Abimanyu (2004) dalam sudiyatno dan sudaryono (2016) adalah mata uang suatu negara relatif terhadap mata uang negara lain. Titik keseimbangan antara kedua mata uang tersebut ditentukan berdasarkan kekuatan penawaran dan permintaan atas kedua mata uang tersebut.

\section{Return on Asset (ROA)}

Return on Asset (ROA) merupakan salah satu rasio yang sering digunakan dalam menilai kinerja perusahaan. Rasio ini menunjukkan kemampuan perusahaan menghasilkan laba dari investasi yang dipergunakan(Hanum, 2009). Semakin besar ROA berarti kinerja perusahaan tersebut semakin baik, karena tingkat pengembalian akan semakin besar. 
Investor akan menyukai perusahaan dengan nilai ROA yang tinggi karena perusahaan dengan nilai ROA yang tinggi dapat menghasilkan tingkat keuntungan yang lebih besar dibandingkan perusahaan dengan nilai ROA yang rendah. Return on Asset (ROA) yang meningkat akan meningkatkan return saham (Puspitasari, 2012).

\section{Debt to Equity Ratio (DER)}

Debt to Equity Ratio (DER) adalah rasio yang menunjukkan perbandingan antara utang dengan modal sendiri (Ismi, et.al, 2016). Tingkat DER yang tinggi menunjukkan komposisi total hutang semakin besar apabila dibandingkan dengan total modal sendiri, sehingga hal ini akan berdampak pada semakin besar pula beban perusahaan terhadap pihak eksternal (kreditur).

\section{Return Saham}

Return yang dimaksudkan dalam penelitian ini adalah return realisasi, yaitu return yang sudah terjadi yang dihitung berdasarkan data historis. Menurut Tandelilin (2001:48) return terdiri dari dua komponen utama, yaitu yield dan capital gain (loss). Yield merupakan komponen return yang mencerminkan aliran kas atau pendapatan yang diperoleh secara periodik dari suatu investasi. Sedangkan, capital gain (loss) merupakan kenaikan (penurunan) harga suatu surat berharga (bisa saham maupun surat berharga jangka panjang) yang bisa memberikan keuntungan (kerugian) bagi investor.

\section{Pengembangan Hipotesis}

\section{Pengaruh Inflasi terhadap Return Saham}

Faktor makro yang bersifat fundamental mempengaruhi return saham adalah inflasi.Tinggi rendahnya inflasi yang terjadi pada suatu perekonomian dapat mempengaruhi pergerakan harga saham perusahaan yang berada pada suatu perekonmian. Inflasi yang tinggi mengurangi tingkat pendapatan rill yang diperoleh investor dari investasi. Sebaliknya, jika tingkat inflasi suatu negara mengalami penurunan maka hal ini merupakan sinyal yang positif bagi investor seiring dengan turunya resiko daya beli uang dan resiko penurunan pendapatan rill.

Penelitian yang dilakukan oleh Laksmiwati (2009) membuktikan bahwa inflasi tidak berpengaruh terhadap return saham. Rusliati dan Fathoni (2011) menunjukkan bahwa inflasi berpengaruh negatif dan signifikan terhadap return saham. Hal ini konsisten dengan hasil penelitian Sudarsono dan Sudiyatno (2016) menunjukkan bahwa inflasi berpengaruh negatif signifikan terhadap return saham. 
Lukman Effendy: Determinan Return Saham...

H1 : Inflasi berpengaruh terhadap return saham

\section{Pengaruh Suku Bunga Indonesia terhadap Return Saham}

Suku bunga adalah faktor perekonomian yang dapat mempengaruhi keuntungan suatu sekuritas. Tinggi rendahnya suku bunga yang ada pada suatu perekonomian dapat mempengaruhi keputusan investor untuk melakukan suatu investasi.Tingkat suku bunga yang meningkat akan menyebabkan peningkatan suku bunga yang diisyaratkan atas investasi pada suatu saham (Widyastuti dan Andamari, 2012). Di samping itu tingkat suku bunga yang meningkat bisa juga menyebabkan investor menarik investasinya pada saham dan memindahkannya pada investasi berupa tabungan ataupun deposito. Perusahaan perbankan sangat terpengaruh dengan adanya perubahan suku bunga. Suku bunga yang tinggi akan mengakibatkan laba perusahaan perbankan akan menurun, karena perbankan kehilangan nasabah peminjam.

Penelitian Laksmiwati (2009) menunjukkan bahwa suku bunga tidak mempengaruhi return saham, sedangkan penelitian Asri dan Suwarta (2014) menunjukkan bahwa suku bunga berpengaruh signifikan terhadap return saham.

H2 : Suku bunga Indonesia berpengaruh terhadap return saham.

\section{Pengaruh Exchange Rateterhadap Return Saham}

Penurunan nilai tukar domestik terhadap mata uang asing merupakan bad news bagi pemegang saham. Penarikan investasi di saham akan dilakukan oleh investor, sehingga menyebabkan adanya penurunan harga saham. Penurunan harga saham akan menyebabkan adanya return negatif.

Penelitian sebelumnya dilakukan oleh Ouma dan Muriu (2014) dalam Sudarsono dan Suyatno (2016) yang menyatakan bahwa nilai tukar berpengaruh positif dan signifikan terhadap return saham.

H3 : Nilai tukar berpengaruh terhadap return saham.

\section{Pengaruh Return on Asset (ROA) terhadap Return Saham}

Return on Asset (ROA) merupakan salah satu faktur fundamental yang banyak digunakan oleh investor untuk melakukan investasi pada suatu perusahaan. Besar atau kecilnya Return on Asset (ROA) dapat mempengaruhi pergerakan harga saham suatu perusahaan. Semakin besar ROA berarti kinerja perusahaan tersebut semakin baik, investor akan menyukai perusahaan dengan nilai pengambalian yang tinggi di atas suku bunga.

Penelitian Puspitasari (2012) menyatakan bahwa Return on Asset memberikan pengaruh negatif dan tidak signifikan terhadap return saham. 
Rosa (2014) membuktikan bahwa profitabilitas yang dihitung dengan menggunakan Return on Asset (ROA) berpengaruh signifikan terhadap return saham. Hal ini juga didukung oleh penelitian Anisa (2015) membuktikan bahwa Return on Asset (ROA) berpengaruh signifikan terhadap return saham. $\mathrm{H} 4$ : Return on Asset (ROA) berpengaruh terhadap return saham.

\section{Pengaruh Debt to Equity Ratio (DER) terhadap Return Saham}

Debt to Equity Ratio (DER) merupakan rasio total hutang terhadap total ekuitas pemegang saham yang dimiliki perusahaan. Tingkat Debt to Equity Ratio (DER) yang tinggi menunjukkan komposisi total hutang (hutang jangka pendek dan hutang jangka panjang) semakin besar apabila dibandingkan dengan total modal sendiri, sehingga ini akan berdampak pada semakin besar pula beban perusahaan terhadap pihak eksternal (para kreditur). Debt to Equity ratio (DER) yang semakin tinggi menunjukkan perusahaan lebih berisiko dibandingkan dengan perusahaan yang memiliki DER rendah. Pemegang saham akan bereaksi terhadap DER yang tinggi dengan melakukan penjualan saham, sehingga akan cenderung menurunkan return saham.

Penelitian Sudarsono dan Sudiyatno (2016) menunjukkan bahwa Debt to Equity Ratio (DER) berpengaruh positif tidak signifikan terhadap return saham, sedangkan penelitian Puspitasari (2012) menunjukkan bahwa Debt to Equity Ratio berpengaruh negatif dan signifikan terhadap return saham. Penelitian Puspitasari (2012) didukung oleh penelitian yang dilakukan oleh Verawati (2014) yang menunjukkan bahwa Debt to Equity Ratio berpengaruh negatif dan signifikan terhadap return saham.

H5 : Debt to Equity Ratio (DER) berpengaruh terhadap return saham.

\section{Kerangka Konseptual}

Gambar 1. Kerangka Konseptual

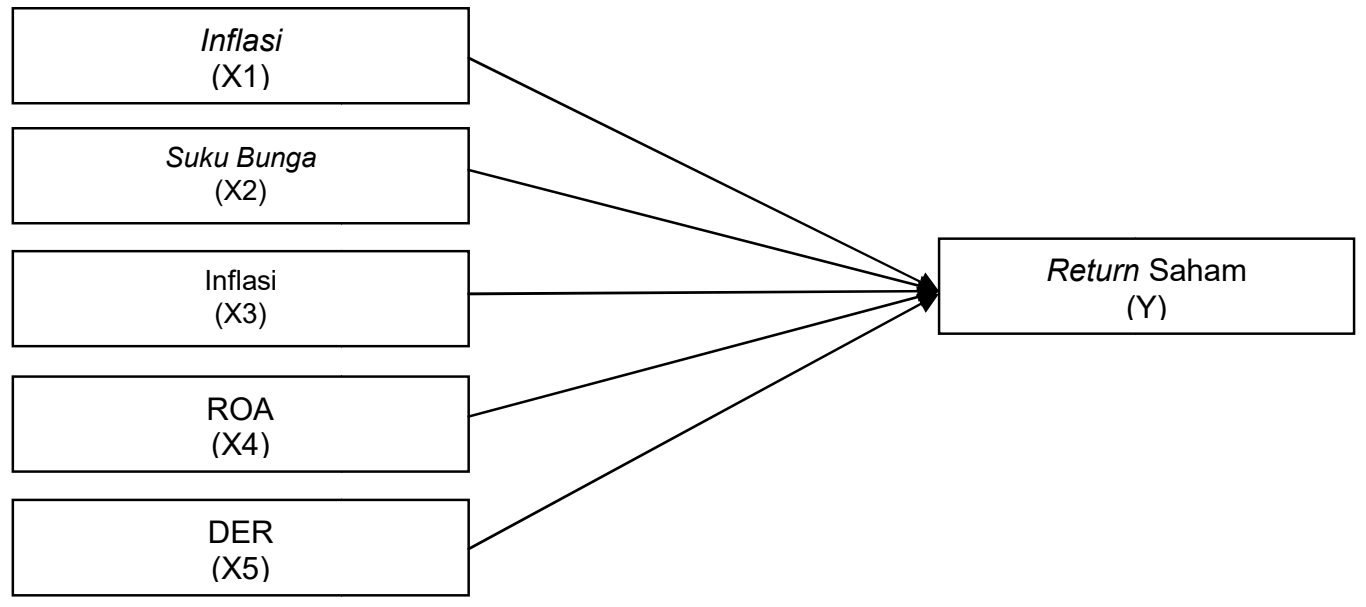


Lukman Effendy: Determinan Return Saham...

\section{METODE PENELITIAN}

\section{Populasi dan Sampel}

Populasi dalam penelitian ini adalah seluruh perusahaan perbankan yang terdaftar di Bursa Efek Indonesia tahun 2012-2016. Teknik pengambilan sampel dalam penelitian ini adalah purposive sampling. Berikut adalah jumlah sampel yang digunakan dalam penelitian ini:

Tabel 1.Teknik Pemilihan Sampel Perusahaan Perbankan yang Terdaftar di BEI

\begin{tabular}{|l|l|c|}
\hline No & Keterangan & Jumlah \\
\hline 1 & Perusahaan perbankan yang terdaftar di BEI. & 43 \\
\hline 2 & $\begin{array}{l}\text { Saham perusahaan perbankan yang tidak aktif } \\
\text { diperdagangkan di BEI pada periode 2012-2016. }\end{array}$ & $(15)$ \\
\hline 3 & $\begin{array}{l}\text { Perusahaan perbankan yang mengalami delisting dan } \\
\text { tidak mempublikasikan laporan keuangan auditan per 31 } \\
\text { Desember 2012-2015. }\end{array}$ & $(3)$ \\
\hline 4 & $\begin{array}{l}\text { Perusahaan yang mengalami kerugian pada periode } \\
\text { 2012-2015. }\end{array}$ & $(3)$ \\
\hline Jumlah Sampel & $\mathbf{2 2}$ \\
\hline Jumlah Observasi (Jumlah sampel x 4 periode) & $\mathbf{8 8}$ \\
\hline
\end{tabular}

\section{Definisi Operasional Variabel}

\section{Return Saham}

Menurut Tandelilin (2001:48) return terdiri dari dua komponen utama, yaitu yield dan capital gain (loss). Pada penelitian ini return yang dimaksudkan adalah return yang bersumber dari perubahan harga saham. Pada penelitian ini return saham dapat dirumuskan sebagai berikut (Jogiyanto, 2013):

Keterangan:

$$
\text { Returnsaham }=\frac{P_{t}-P_{t-1}}{P_{t-1}}+1
$$

$\mathrm{P}_{\mathrm{t}} \quad=$ Harga saham tahun sekarang

$\mathrm{P}_{\mathrm{t}-1} \quad=$ Harga saham tahun sebelumnya

\section{Inflasi}

Inflasi adalah ukuran ekonomi yang memberikan gambaran tentang meningkatnya harga rata-rata barang dan jasa yang di produksi pada suatu sistem perekonomian (Prihantini, 2009). Inflasi yang digunakan pada 
penelitian ini adalah inflasi tahunan yang diperoleh dari situs bank Indonesia yaitu www.bps.go.id.

\section{Suku Bunga Indonesia}

Pada penelitian ini suku bunga Indonesia yang digunakan adalah BI rate. BI rate adalah suku bunga dengan tenor satu bulan yang diumumkan oleh Bank Indonesia secara periodik untuk jangka waktu tertentu yang berfungsi sebagai sinyal (stance) kebijakan moneter (Prakoso dan Boentoro, 2012). Pada penelitian ini suku bunga yang di gunakan adalah BI rate ratarata setahun yang diperoleh dari situs bank Indonesia yaitu www.bi.go.id.

\section{Exchange Rate}

Nilai tukar adalah harga valuta asing yang dinilai dalam rupiah. Pada penelitian ini, exchange rate adalah nilai tukar mata uang rupiah terhadap mata uang dollar amerika.

\section{Return on Asset (ROA)}

Return on Asset (ROA) merupakan rasio profitabilitas yang digunakan untuk mengukur efektivitas perusahaan di dalam menghasilkan keuntungan dengan memanfaatkan aktiva yang dimilikinya (Sudarsono dan Sudiyatno, 2016). Pada penelitian ini Return on Asset (ROA) yang digunakan adalah Return on Asset (ROA) tahun sebelumnya. Return on Asset (ROA) dalam penelitian ini dihitung dengan rumus (Horne dan Wachowicz, 2012: 182):

$$
\operatorname{ROA}_{(t-1)}=\frac{\text { Labanetosetelahpajak }_{(t-1)}}{\text { TotalAset }_{(t-1)}} \times 100 \%
$$

\section{Debt to Equity Ratio (DER)}

Debt to Equity Ratio (DER) merupakan perbandingan antara total hutang terhadap total ekuitas pemegang saham yang dimiliki perusahaan. Pada penelitian ini Debt to Equity Ratio (DER) yang digunakan adalah Debt to Equity Ratio (DER) tahun sebelumya. Debt to Equity Ratio (DER) dalam penelitian ini dihitung dengan menggunakan rumus (Horne dan Wachowicz, 2012: 169):

$$
\operatorname{DER}_{(t-1)}=\frac{\operatorname{Totalutang}_{(t-1)}}{\text { Ekuitaspemegangsaham }_{(t-1)}} \times 100 \%
$$




\section{Prosedur Analisis Data}

\section{Analisis Statistik Deskriptif}

Statistik deskriptif memberikan gambaran atau deskripsi suatu data yang dilihat dari nilai rata-rata (mean), minimum, maksimum serta standar deviasi (Ghozali, 2005: 19).

\section{Uji Asumsi Klasik}

Uji asumsi klasik digunakan untuk mengetahui apakah hasil regresi linier berganda terbebas dari penyimpangan asumsi klasik. Uji asumsi klasik yang dilakukan dalam penelitian ini adalah uji multikolinieritas, uji heteroskedastisitas, uji autokorelasi, dan uji normalitas.

\section{Pengujian Hipotesis Koefisien Determinasi $\left(\mathbf{R}^{2}\right)$}

Koefisien determinasi $\left(R^{2}\right)$ pada intinya mengukur seberapa jauh kemampuan model dalam menerangkan variasi variabel dependen (Ghozali, 2005: 83). Dari sini akan diketahui seberapa besar variabel dependen akan mampu dijelaskan oleh variabel independennya, sedangkan sisanya dijelaskan oleh sebab-sebab lain diluar model. Nilai koefisien determinasi adalah antara 0 dan 1 . Semakin besar nilai $\mathrm{R}^{2}$, semakin baik kualitas model karena semakin dapat menjelaskan hubungan antara variabel dependen dan independen. (Winarno, 2015:4.9).

\section{Uji Anova}

Uji anova pada dasarnya menunjukkan apakah semua variabel independen atau bebas yang dimasukan dalam model mempunyai pengaruh secara bersama-sama terhadap variabel dependen atau terikat (Ghozali, 2005: 84). Pengujian ini dilakukan dengan menggunakan tingkat signifikansi $a=0,05$. Jika nilai signifikansi $F \leq 0,05$ berarti terdapat pengaruh semua variabel independen secara bersama-sama terhadap variabel dependen. Jika nilai signifikansi $F>0,05$ berarti tidak terdapat pengaruh antara semua variabel independen terhadap variabel dependen.

\section{Uji Signifikansi Parameter Individual (Uji Statistik t)}

Uji statistik t pada dasarnya menunjukkan seberapa jauh pengaruh satu variabel independen secara individual dalam menerangkan variasi variabel dependen (Ghozali, 2005: 85). Pengujian ini untuk mengetahui variabel independen secara individu berpengaruh terhadap variabel dependen. Adapaun hipotesis yang digunakan dalam pengujian ini adalah: 
1. $H_{0}: b 1=0$, artinya variabel-variabel bebas tidak memiliki pengaruh yang signifikan terhadap variabel terikat.

2. $H_{a}: b 1 \neq 0$, artinya variabel-variabel bebas memiliki pengaruh yang signifikan dengan variabel terikat.

Kesimpulan yang diambil dalam uji $t$ ini dapat dilakukan dengan melihat karakteristik pengambilan keputusan sebagai berikut:

1. Jika $t_{\text {hitung }}>t_{\text {tabel }}$ dan tingkat signifikansi (a) $<0,05$, maka $H_{0}$ ditolak dan $\mathrm{H}_{\mathrm{a}}$ diterima. Ini berarti variabel independen berpengaruh signifikan terhadap variabel dependen.

2. Jika $t_{\text {hitung }}<t_{\text {tabel }}$ dan tingkat signifikansi $(a) \geq 0,05$, maka $\mathrm{H}_{0}$ diterima dan $\mathrm{H}_{\mathrm{a}}$ ditolak. Ini berarti variabel independen tidak berpengaruh signifikan terhadap variabel dependen.

\section{HASIL ANALISIS DAN PEMBAHASAN}

\section{Hasil Analisis Data}

\section{Hasil Analisis Statistik Deskriptif}

Berikut dapat disajikan hasil analisis deskriptif dalam penelitian ini:

Tabel 2. Statistik Deskriptif

\begin{tabular}{|l|l|l|l|l|l|l|}
\hline & RETURN & INFLASI & BUNGA & $\begin{array}{l}\text { EXCHANGE } \\
\text { RATE }\end{array}$ & ROA & DER \\
\hline Mean & 1.113648 & 5.777500 & 6.760000 & 12.977 & 1.444466 & 14.08433 \\
\hline Median & 1.009000 & 5.855000 & 6.960000 & 12.977 & 1.256500 & 13.67250 \\
\hline Maximum & 3.979000 & 8.380000 & 7.540000 & 13.864 & 3.389000 & 31.16300 \\
\hline Minimum & 0.600000 & 3.020000 & 5.580000 & 12.171 & 0.135000 & 7.550000 \\
\hline Std. Dev. & 0.478565 & 2.610006 & 0.827515 & 709,0431 & 0.794040 & 4.389059 \\
\hline Observations & 88 & 88 & 88 & 88 & 88 & 88 \\
\hline
\end{tabular}

Sumber : Data diolah 2017

Pada tabel 2, dari 88 sampel data perusahaan memiliki nilai return saham (RETURM) perusahaan terkecil (Minimum) yakni sebesar 0,600 dimiliki oleh Bank Tabungan Negara Tbk yang terjadi pada tahun 2013, sedangkan nilai return saham terbesar (Maximum) sebesar 3,979 dimiliki oleh Bank Rakyat Indonesia Agro Niaga Tbk yang terjadi pada tahun 2016. Return saham secara rata-rata (Mean) mengalami perubahan positif dengan ratarata return saham sebesar 1,11 . Standar deviasi (Std. Dev) return saham sebesar 0,47 yang nilainya lebih kecil dari nilai rata-rata return saham sebesar 1,11. Kondisi ini menunjukkan bahwa perusahaan yang menjadi sampel penelitian tidak mempunyai fluktuasi data yang tinggi selama periode 2012-2016. Nilai tengah (median) return saham dari 88 perusahaan sebesar 1. 
Pada Tabel 2, nilai inflasi (INFLASI) terkecil (Minimum) yakni sebesar 3,02\% terjadi pada tahun 2016, sedangkan nilai inflasi terbesar (Maximum) sebesar 8,38\% terjadi pada tahun 2013. Inflasi secara rata-rata (Mean) mengalami perubahan positif dengan rata-rata inflasi sebesar $5,77 \%$. Standar deviasi (Std. Dev) inflasi sebesar 2,61\% yang nilainya lebih kecil dari nilai rata-rata inflasi sebesar $5,77 \%$. Kondisi ini menunjukkan bahwa inflasi tidak mempunyai fluktuasi data yang tinggi selama periode 2013-2016. Nilai tengah (median) inflasi sebesar 5,855\%.

Statistik deskriptif menunjukkan nilai suku bunga Indonesia (BUNGA) terkecil (Minimum) yakni sebesar 5,58\% terjadi pada tahun 2016, sedangkan nilai suku bunga Indonesia terbesar (Maximum) sebesar 7,54\% terjadi pada tahun 2014. Suku bunga Indonesia secara rata-rata (Mean) mengalami perubahan positif dengan rata-rata suku bunga Indonesia sebesar 6,76\%. Standar deviasi (Std. Dev) suku bunga Indonesia sebesar 0,82\% yang nilainya lebih kecil dari nilai rata-rata suku bunga Indonesia sebesar 6,76\%. Kondisi ini menunjukkan bahwa suku bunga Indonesia tidak mempunyai fluktuasi data yang tinggi selama periode 2013-2016. Nilai tengah (median) suku bunga Indonesia sebesar 6,960\%.

Statistik deskriptif menunjukkan Exchange Rate terkecil sebesar 12.171 terjadi pada tahun 2013, sedangkan terbesar (Maximum) sebesar 13.864 terjadi pada tahun 2015. Rata-rata (Mean) nilai tukar adalah sebesar 12.977. Standar deviasi (Std. Dev) exchange rate 709,0431 yang nilainya lebih kecil dari nilai rata-rata sebesar 12.977. Kondisi ini menunjukkan bahwa suku bunga Indonesia tidak mempunyai fluktuasi data yang tinggi selama periode 2013-2016. Nilai tengah (median) exchange rate sebesar 12.977

Berdasarkan tabel 2, dapat diketahui bahwa dari 88 sampel data perusahaan nilai Return on Asset (ROA) perusahaan terkecil (Minimum) yakni sebesar $0,135 \%$ dimiliki oleh Bank Permata Tbk yang terjadi pada tahun 2015, sedangkan nilai Return on Asset terbesar (Maximum) sebesar 3,389\% dimiliki oleh Bank Rakyat Indonesia Tbk yang terjadi pada tahun 2012. Return on Asset secara rata-rata (Mean) mengalami perubahan positif dengan rata-rata Return on Asset sebesar 1,44\%. Standar deviasi (Std. Dev) Return on Asset sebesar 0,79\% yang nilainya lebih kecil dari nilai rata-rata Return on Asset sebesar 1,44\%. Kondisi ini menunjukkan bahwa perusahaan yang menjadi sampel penelitian tidak mempunyai fluktuasi data yang tinggi selama periode 2012-2015. Nilai tengah (median) Return on Asset dari 88 perusahaan sebesar $1,256 \%$.

88 sampel data perusahaan memiliki nilai Debt to Equity Ratio (DER) perusahaan terkecil (Minimum) yakni sebesar 7,550\% dimiliki oleh Bank Woori Saudara Indonesia Tbk yang terjadi pada tahun 2013, sedangkan nilai 
Debt to Equity Ratio terbesar (Maximum) sebesar 31,163\% dimiliki oleh Bank Woori Saudara Indonesia Tbk yang terjadi pada tahun 2014. Debt to Equity Ratio secara rata-rata (Mean) mengalami perubahan positif dengan rata-rata Debt to Equity Ratio sebesar 14,08\%. Standar deviasi (Std. Dev) Debt to Equity Ratio sebesar $4,38 \%$ yang nilainya lebih kecil dari nilai rata-rata Debt to Equity Ratio sebesar $14,08 \%$. Kondisi ini menunjukkan bahwa perusahaan yang menjadi sampel penelitian tidak mempunyai fluktuasi data yang tinggi selama periode 2012-2015. Nilai tengah (median) Debt to Equity Ratio dari 88 perusahaan sebesar $13,672 \%$.

\section{Hasil Uji Asumsi Klasik}

Berdasarkan hasil uji asumsi klasik yang telah dilakukan, hanya uji normalitas yang belum memenuhi persyaratan.Guna memenuhi persyaratan normalitas salah satu cara yang dapat digunakan adalah melakukan transformasi model. Variabel yang akan ditransformasi ke dalam bentuk logaritma natural (In) adalah variabel dependen. Berikut hasil uji asumsi klasik setelah dilakukanya transformasi model:(1) Uji Normalitas menggunakan One-Sample Kolmogorov-Smirnov Test memiliki Asym. Sig (2tailed) sebesar 0,138 lebih besar dari $a=0,05$ yang berarti data berdistribusi normal; (2) Uji Multikolinearitas untuk model tersebut memiliki nilai Tolerance diatas 0,01 dan VIF dibawah 10 untuk seluruh variabel; (3) Uji Heterokedastisitas dilakukan dengan menggunakan uji glejser dan memiliki nilai di atas 0,05 yang berarti tidak terjadi heteroskedastisitas; (4) Pada Uji Autokolerasi dengan menggunakan nilai Durbin - Watson memiliki nilai 2,213, yang berada antara nilai DU 1,863, sampai dengan 4-du, sehingga dapat disimpulkan tidak terdapat masalah autokorelasi.

\section{Model Regresi}

Berdasarkan tabel 3, maka dapat disusun persamaan regresi data panel setelah transformasi model sebagai berikut:

$$
\begin{aligned}
\text { LnReturn }_{i t}= & -0,180-0,017 \text { Inflasi }-0,036 \text { Bunga }-3,69 \text { E005Exchange } \\
& -0,043 \text { ROA }+0,04 \text { DER }+\varepsilon_{i t}
\end{aligned}
$$


Lukman Effendy: Determinan Return Saham...

Tabel 3. Pengaruh Insentif Pajak dan Insentif Non Pajak Terhadap Manajemen Laba

\begin{tabular}{|c|c|c|c|}
\hline \multicolumn{4}{|c|}{ 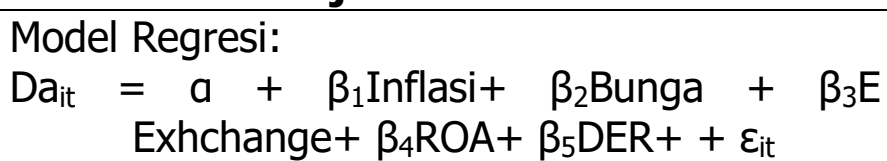 } \\
\hline Variabel & Koefisien & $\mathrm{t}$ & Sig. \\
\hline Constant & $-0,180$ & $-0,233$ & 0,816 \\
\hline Inflasi & $-0,017$ & $-1,273$ & 0,206 \\
\hline Bunga & $-0,036$ & $-0,829$ & 0,410 \\
\hline Exchange & 3,691E-005 & 0,669 & 0,505 \\
\hline ROA & $-0,043$ & $-0,871$ & 0,387 \\
\hline DER & 0,04 & 0,423 & 0,674 \\
\hline $\begin{array}{l}\text { R Square } \\
0,605)\end{array}$ & & & $=$ \\
\hline
\end{tabular}

Sumber: Data Diolah

Pada tabel 3, dapat dilihat bahwa semua variabel yang diuji memiliki pengaruh yang tidak signifikan, karena tingkat signifikansinya lebih besar dari 0,05. Dari persamaan regresi tersebut dapat dilihat bahwa ROA memiliki koefisien paling dominan dibandingkan dengan variabel-variabel lainnya. Variabel exchange memiliki koefisien yang paling kecil dibandingkan dengan variabel-variabel lainnya.

Pada tabel 3, Uji anova menunjukkan bahwa besarnya $\mathrm{F}$ hitung sebesar 1,620 , dengan signifikansi sebesar 0,605 . Hal ini berarti variabel bebas tidak mampu menjelaskan perubahan return saham secara simultan. Model yang digunakan dalam penelitian ini tidak memenuhi asumsi goodness of fit model.

Koefisien determinasi pada tabel 3, menunjukkan bahwa nilai R Square adalah sebesar 0,032. Ini menunjukkan bahwa variasi return saham ditentukan oleh variabel independen dalam penelitian ini, sementara 0,968 dijelaskan oleh variabel lain yang tidak diikutkan dalam penelitian ini.

\section{Pembahasan}

Berdasarkan hasil penelitian analisis dapat dilihat bahwa perubahan inflasi tidak memberikan kontribusi terhadap return saham. Pada saat inflasi meningkat pemerintah juga akan meningkatkan suku bunga acuannya. Investor lebih memilih untuk berinvestasi pada tabungan atau deposito daripada saham karena dapat memberikan tingkat pengembalian yang lebih tinggi dan resiko yang lebih rendah. Sehingga pada saat inflasi tinggi dapat menyebabkan harga saham perusahaan turun. Harga saham menurun menyebabkan return saham juga akan turun. Namun, hasil penelitian ini menunjukkan hal berbeda.. Sepanjang tahun 2013 sampai tahun 2016 inflasi 
yang terjadi tergolong inflasi ringan $(<10 \%)$. Oleh karena itu, inflasi yang terjadi selama tahun 2013-2016 tidak begitu mengganggu perekonomian secara nasional. Perekonomian indonesia yang stabil tidak akan mempengaruhi return saham perusahaan. Hasil penelitian ini bertolak belakang dengan penelitian Rusliati dan Fathoni (2011) dan penelitian Sudarsono dan Sudiyatno (2016) yang menunjukkan bahwa inflasi berpengaruh negatif signifikan terhadap return saham. Akan tetapi, hasil penelitian ini sama dengan hasil penelitian yang dilakukan oleh Laksmiwati (2009) yang menyimpulkan bahwa variabel inflasi tidak berpengaruh terhadap return saham.

Semakin tinggi suku bunga, maka akan meningkatkan imbalan yang diterima oleh pemberi pinjaman. Tingkat suku bunga yang meningkat dapat menyebabkan investor menarik investasinya pada saham dan memindahkannya pada investasi berupa tabungan atau deposito karena tingkat pengembalian yang akan diterima lebih besar. Suku bunga meningkat akan menyebabkan harga saham menurun. Harga saham menurun menyebabkan return saham juga akan turun. Namun, hasil penelitian ini dapat disimpulkan bahwa perubahan suku bunga Indonesia tidak memberikan kontribusi terhadap return saham, karena perubahan suku bunga yang ditetapkan oleh Bank Inodnesia dari sisi peningkatan ataupun penurunan tidak signifikan. Hasil penelitian ini bertolak belakang dengan penelitian Asri dan Suwarta (2014) yang menunjukkan bahwa suku bunga berpengaruh signifikan terhadap return saham. Akan tetapi, hasil penelitian ini konsisten dengan penelitian yang dilakukan oleh Laksmiwati (2009) yang menyimpulkan bahwa variabel suku bunga tidak berpengaruh terhadap return saham.

Semakin tinggi nilai tukar mata uang suatu negara, akan menyebabkan akan semakin tinggi pula return saham. Meningkatnya nilai tukar rupiah terhadap dolar, menjanjikan investor ada peningkatan penghasilan berupa return, dan pasar ekuitas akan tampak lebih menarik bagi investor. Namun, dalam penelitian ini, naik dan turunnya exchange rate tidak berpengaruh terhadap return. Standar deviasi yang relatif kecil dibandingkan dengan nilai rata-rata menunjukkan pergerakan nilai tukar tidak signifikan untuk dapat mempengaruhi pergerakan harga saham, sehingga return saham juga tidak terpengaruh. Penelitian ini berbeda dengan hasil penelitian Sudarsono dan Suyatno (2016) yang menemukan pengaruh positif nilai tukar mata uang terhadap return saham.

Return on Asset adalah rasio yang digunakan untuk mengukur kemampulabaan perusahaan dikaitkan dengan aset yang dimiliki. Perusahaan dengan nilai Return on Asset yang tinggi akan dapat menarik banyak investor 
untuk menanamkan dananya pada perusahaan tersebut. Hal ini akan berdampak pada meningkatnya harga saham perusahaan tersebut. Harga saham meningkat akan meningkatkan return saham. Dalam penelitian ini ternyata Return on Asset memberikan pengaruh yang signifikan terhadap return. ROA gagal memberikan pandangan kepada investor terkait dengan prospek perusahaan ke depan. Hasil peneltian ini bertolak belakang dengan penelitian yang dilakukan oleh Prihantini (2009), Rosa (2014), dan Anisa (2015) yang menyimpulkan bahwa ROA berpengaruh positif dan signifikan terhadap return saham. Akan tetapi, hasil penelitian ini konsisten dengan hasil penelitian yang dilakukan oleh Puspitasari (2012) dan Sudarsono dan Sudiyatno (2016) yang menyimpulkan bahwa variabel ROA tidak berpengaruh terhadap return saham.

Berdasarkan hasil penelitian ini dapat dikatakan bahwa perubahan DER tidak memberikan kontribusi terhadap return saham. Investor menganggap perusahaan menetapkan kebijakan utangnya untuk tujuan yang tepat, yaitu ingin meningkatkan pendapatan perusahaan. Perusahaan dengan pendapatan yang stabil cenderung mempunyai kemampuan membayar hutang lebih baik dibandingkan perusahaan dengan pendapatan yang berfluktuasi sehingga investor lebih nyaman dengan DER yang tinggi pada perusahaan dengan pendapatan yang stabil. Sehingga tinggi atau rendahnya DER tidak mempengaruhi keputusan investor dalam melakukan suatu invetasi. Hasil penelitian ini konsisten dengan penelitian Nathaniel (2008) dan Widyastuti dan Andamari (2012) yang menunjukkan bahwa DER tidak berpengaruh terhadap return saham. Akan tetapi, hasil penelitian ini bertolak belakang dengan hasil penelitian yang dilakukan oleh Sudarsono dan Sudiyatno (2016) yang menyimpulkan bahwa variabel DER berpengaruh positif dan signifikan terhadap return saham.

\section{KESIMPULAN DAN SARAN}

\section{Kesimpulan}

Berdasarkan penelitian tentang pengaruh inflasi, suku bunga, exchange rate, return on asset, dan debt to equity ratio, terhadap return saham menunjukkan bahwa seluruh variabel independen tidak berpengaruh terhadap variabel return saham.

\section{Saran}

Berdasarkan hasil penelitian dan pembahasan serta beberapa kesimpulan dan keterbatasan pada penelitian ini, maka peneliti dapat memberikan saran sebagai berikut: (1) Dalam penelitian selanjutnya 
diharapkan untuk memperpanjang periode pengamatan dan menggunakan periode pengamatan terbaru sehingga diharapkan hasil yang diperoleh akan lebih dapat digeneralisasikan dan menghasilkan analisis yang lebih baik. (2) Dalam penelitian selanjutnya sebaiknya menggunakan faktor internal dan faktor eksternal lain yang tidak digunakan pada penelitian ini yang dianggap memiliki pengaruh kuat terhadap return saham. (3) Dalam penelitian selanjutnya sebaiknya menggunakan perusahaan selain perusahaan perbankan, misalnya perusahaan manufaktur.

\section{DAFTAR PUSTAKA}

Adiputra, I Putu Wahyu. 2017. Pengaruh Return On Asset (Roa), Debt To Equity Ratio (Der), Inflasi, Dan Suku Bunga Indonesia Terhadap Return Saham. Skripsi. Universitas Mataram, Mataram.

Anisa, Nesa. 2015. Analisis Faktor-faktor yang Mempengaruhi ReturnSaham. Perbanas Review Vol. 1, No. 1, November 2015.

Asri, I Gusti Ayu Amanda Yulita, dan I Ketut Suwarta. 2014. Pengaruh Faktor Fundamental dan Ekonomi Makro Pada ReturnSaham Perusahaan Consumer Good. E-Jurnal Akuntansi Universitas Udayana. 8.3 (2014): 353-370.

Ghozali, Imam. 2005. Aplikasi Analisis Multivariate dengan Program SPSS. Semarang. Badan Penerbit Universitas Diponegoro.

Hartono, Jogiyanto. 2013. Teori Portofolio dan Analisis Investasi, Edisi Kedelapan. Penerbit BPFE Yogyakarta.

Horne, James C. Van, dan John M. Wachowicz, Jr. 2012. Prinsip-prinsip Manajemen Keuangan. Penerbit Salemba Empat, Jakarta.

Laksmiwati, Mia. 2009. Pengaruh Faktor-faktor Ekonomi Makro Terhadap Return Saham Jakarta Islamic Index di Bursa Efek Indonesia (Januari 2006 - September 2009). Jurnal Ekonomika dan Manajemen. Vol. 1 No. 2.

Patriawan, Dwiatma. 2011. Analisis Pengaruh Earning Per Share (EPS), Return on Equity (ROE), dan Debt to Equity Ratio (DER) Terhadap Harga Saham. Skripsi. Universitas Diponegoro, Semarang.

Prihantini, Ratna. 2009. Analisis Pengaruh Inflasi, Nilai Tukar, ROA, DER, dan CR Terhadap Return Saham. Tesis. Universitas Diponegoro, Semarang.

Ross, A. Stephen. 1997. The Arbitrage Theory of Capital Asset Pricing. Journal of Economic Theory 13, 341-360.

Rusliati, Ellen, dan Syarah Nurul Fathoni. 2011. Inflasi, Suku Bunga Deposito dan Return Pasar Terhadap ReturnSaham pada Industri Barang Konsumsi yang Terdaftar di BEI 2006-2009. Jurnal Bisnis dan Akuntansi Vol. 13, No. 2, Agustus 2011, HIm 107-118. 
Sudarsono, Bambang, dan Bambang Sudiyatno. 2016. Faktor-faktor yang Mempengaruhi ReturnSaham. Jurnal Bisnis dan Ekonomi (JBE), Maret 2016, hal. 30-51.

Sudarsono, Bambang, dan Bambang Sudiyatno. 2016. Faktor-faktor yang Mempengaruhi ReturnSaham. Jurnal Bisnis dan Ekonomi (JBE), Maret 2016, hal. 30-51.

Sugiyono. 2013. Metode Penelitian Kombinasi (Mixed Methods). Bandung: Alfabeta.

Tandelilin, Eduardus. 2001. Analisis Investasi dan Manajemen Portofolio Edisi 1. Universitas Gadjah Mada, Yogyakarta.

Widyastuti, Tri, dan Basis G. Andamari. 2012. Faktor Fundamental, Suku Bunga, dan Nilai Tukar Terhadap Return Saham. Jurnal Akuntansi \& Auditing. Volume 10, No. 1.

www.bankbba.co.id

www.bi.go.id diakses 4 Februari 2017

www.bni.co.id diakses 5 Februari 2017

www.bps.go.id diakses 4 Februari 2017

www.briagro.co.id diakses 5 Februari 2017

www.btn.co.id diakses 5 Februari 2017

www.idx.co.id diakses 4 Februari 2017

www.sahamok.com diakses 4 Februari 2017 